\title{
Shifting from Government Bursaries to a Loan Scheme in Higher Education: Exploring the Zambian Experience in Student Financial Aid
}

\author{
Gift Masaiti, Kapambwe Mwelwa, and Nelly Mwale
}

\begin{abstract}
One of the current critical issues in higher education in Africa and globally is about making student loans available in a sustainable and cost-effective manner. The argument is more complicated for Africa because of the complexities associated with loan schemes and the general austerity that African countries find themselves in. This article presents a case study and conceptualizes the scenario of shifting government bursaries to a student loan scheme in Zambia's higher education sector. Based on student views $(\mathrm{N}=729)$ and international experience, the article presents student reactions to the announcement of the implementation of the loan scheme in Zambia. Other issues explored in detail include cost-effectiveness and sustainability, loan conditionalities and forms of assistance to poor students. The article also highlights, and provokes policymakers with, questions on student loan schemes based on international experience. These are related to the modalities of who bears the ultimate risks; when and how to make the recoveries; and difficulties associated with "means testing" for would-be beneficiaries. The article uses quantitative methodological perspectives, in which "descriptive statistics" and "factor analysis" are employed. The major finding is that Zambian students are not opposed to the introduction of the student loan scheme, instead they see it as a cost-effective way of assisting students from a vulnerable background. The article strongly recommends exploring in detail the situation in other countries, so that all strengths and weaknesses are identified and carefully considered, before implementing the scheme.
\end{abstract}


Key words: Student Loan Scheme; Cost Sharing, Funding, Government Bursaries; Zambia

Un des problèmes les plus importants pour l'enseignement supérieur aujourd'hui en Afrique et dans le monde est de mettre à disposition des étudiants des systèmes de prêts qui soient durables et rentables. Le débat est particulièrement compliqué en Afrique à cause de la complexité des systèmes de prêts et de l'austérité générale à laquelle sont confrontés les pays africains. Cet article présente une étude de cas : il conceptualise le changement d'un système de bourses étudiantes à un système de prêts étudiants en Zambie. Cet article s'appuie sur l'opinion des étudiants $(\mathrm{N}=729)$ et l'expérience internationale pour présenter la réaction des étudiants zambiens à l'annonce de la mise en place d'un système de prêts. Il explore aussi en détails les problèmes suivants : la rentabilité et la durabilité, les conditions d'accès et les aides financières disponibles pour les étudiants pauvres. En s'appuyant sur l'expérience internationale, cet article souligne par ailleurs, dans le but de provoquer les législateurs, les questionnements associés aux systèmes de prêts étudiants. Cela inclut notamment la question de la personne qui assume le risque final, de quand et comment assurer le remboursement et des difficultés associées à l'évaluation des ressources des futurs bénéficiaires. Cet article utilise une méthodologie quantitative, plus précisément il emploie des statistiques descriptives et une analyse factorielle. La principale conclusion de cet article est que les étudiants zambiens ne sont pas opposés à l'instauration d'un système de prêts étudiants : ils considèrent au contraire que c'est une manière rentable d'aider les étudiants issus de milieux vulnérables. Cet article recommande fortement d'analyser de manière détaillée la situation dans d'autres pays pour identifier et examiner attentivement les forces et les faiblesses des systèmes de prêts avant de mettre en place un tel dispositif en Zambie.

\section{Background and Current Status}

For a long time now, students at Zambia's higher learning institutions, especially in the public university sector, have been benefiting from a "free" bursary scheme, which has covered tuition expenses as well as stipends for general upkeep. This policy provision was thought to help Zambia develop through widespread provision of education to as many citizens as possible (UNESCO, I99I; Kelly, I99I; Masaiti \& Chita, 20I4). As a result, after the creation of the first public university in I966, Zambia followed "a full government support model" in both the management of the institutions and the provision of bursaries for student tuition and stipends (Coburn, I993). This trend continued with the establishment of the second public university, which was opened in I986. The role of the students was therefore merely to make themselves available for school, and everything else followed suit (Coburn, I993). It was later discovered that funding for bursary provisions took a great toll on educational institutions, faced with multifaceted challenges such as financial austerity, faculty recruitment and retention, and lack of maintenance of physical facilities (Ministry of Education [MOE], I992). In order to improve the financial situation of public universities, the Zambian government crafted policy guidelines regarding financing of higher education based on cost sharing (MOE, I996). Accordingly, all students in higher education institutions in Zambia were required to pay tuition fees, board and accommodation. More specifically, support for needy students to higher education was now based on a loan scheme. As stated in MOE (I996 p. I05): “...Government support for students in higher education institutions will be in form of loans that will be recovered during the students' subsequent working life". Today, I8 years after the student loan policy was formulated, it has never really been implemented despite many political pronouncements by successive governments. We have to specify here that the loan policy currently in place is meant to cater for students at both public and private universities. In the past, only students enrolled at the two oldest and largest public universities were recipients of the bursary schemes. It is only now that all students in higher education will have an opportunity to access student loans.

Currently, there are 37 universities in Zambia: five are public and 32 are private. Another three are seeking registration, which will bring the total to 40 . Three public universities are well established, while two are just upgraded from college status. All public universities are supported by the government through grants and subventions (MOE, 20IO). The cost sharing policy at the two oldest universities has taken the form of a "dual cost tuition model" where there are two categories of students. In this system, the government decides on the numbers of students to be supported and pays full tuition for them, while the rest pay tuition fees. From inception in I966 to 1996, the government used to sponsor all students admitted to the two public universities, arguing that university costs are substantial and that Zambia needed to develop much needed human resources.

From I996 to date, the majority of the students at these two public universities, about 80 percent, are still sponsored by the government, which pays full accommodation and up to 75 percent of the tuition fees, and gives each student a living allowance to cover food and personal educational items (Southern African Regional Universities Association 
[SARUA], 20I2). In addition, there are allowances for research courses and vacation training. Usually, students at the University of Zambia (UNZA) and Copperbelt University (CBU) are selected on merit (based on scores), not means tested (based on financial need). Depending on the number of study places available, the government sponsors the most successful secondary school leavers; those who score the sum of below Io points (mostly distinction and merits in 5 subjects) are given priority and preference. For instance in 2007 , about US\$10 million were committed to student sponsorship and this figure has kept on increasing by approximately I 2 percent annually. The remainder of the students, about 20 percent, are sponsored by other public and private bodies, or are self-sponsored (MOE, 20IO; SARUA, 20I2). As of 20II, the Bursaries Committee had disbursed more than US\$94.7 million in loans (loans only on paper-these were still bursaries) to university students pursuing studies at UNZA and CBU. The total number of beneficiaries by 3I December 20I0 stood at I0,047 students from both UNZA and CBU (Parliamentary session, 9 June, 2OII). Including distance and "parallel" students, UNZA had a total enrolment of 16,000 students and CBU of about 8,000 by 2013 . This implies that about $\mathrm{I} 6,000$ fulltime students are on the government bursary scheme. These numbers keep escalating year after year because of rising admissions. Correspondingly, government allocation and expenditures to the Bursaries Committee keep growing at exponential levels to a point where funding bursaries has become unsustainable (MOE, 20I0; Parliamentary Assurances Committee, 20II).

Although the loan scheme started in 2004, the recovery of the loans had not commenced by 201 I, because the Statutory Instrument No.I82 of 1973 was deemed to be weak on the repayment of the loans. This jeopardized the recovery process, which should have commenced in July 2009 with the first recipients of the loans-who graduated in July 2008. Apart from these developments, the Ministry of Education was in the process of reviewing the legal framework and the establishment of the Zambia Higher Education Loans Board (ZAHELB), which would be responsible for the administration of all higher education loans and scholarships offered by the government. A memorandum of understanding (MoU) between the government through the Ministry of Education and a financial institution was to be signed for the administration of the scheme, though this never materialized.

Another interesting trend in Zambia's higher education is the existence of the dual track system. The dual track system developed out of necessity because government could not keep pace with the exponentially rising costs of providing higher education, and decision-makers could not face the political expense of attempting any meaningful reform to the policies of financing higher education. In this compromised approach, the public universities in Zambia offered additional seats to fee-paying students, as a way of generating income locally. The number of students who pay fees at the two largest public universities is still very small; hence austerity in these institutions is increasing. On average, tuition fees ranged between US\$1,000 and US\$2,500 annually in these two public universities, with a majority of the students supported by government. Zambia's newest public university, Mulungushi University, operates on a "unit cost tuition model", even though government supports it for capital projects related to infrastructure development (GRZ, 20I3). It is autonomous in decision making and operates like a business. All services provided by the institution are provided for at cost and are borne by the consumer. This university, which charges fees between US\$4,000 to US\$6,000 annually, has been relatively successful though it is operating on a trial basis. If successful, it will be replicated in all government funded universities.

Though there are many other factors which have reduced government funding to public universities in real terms, the trend shows a clear correlation between the ever increasing student numbers sponsored by government and the progressive failure to finance the universities effectively-especially capital projects related to expansion of infrastructure and staff emoluments (Beele, 20I2; Masaiti 20I3b). To complicate matters further, the government, responsible for paying faculty salaries and capital grants and a major sponsor of students, disapproves any fee increases by universities (Beele, 20I2; Masaiti \& Shen, 2013).

\section{Problem and Context}

Sponsoring students through taxes is no longer a viable and sustainable measure, especially in an environment of competing needs by different sectors, and in a context of an ever expanding student population seeking higher education (Mwelwa, 20I4; MOE I996). Clearly, government resources cannot sustain free higher education in Zambia (Serpell, 20I2; Masaiti, 20I3b). As mentioned above, funding for bursary provisions has taken a great toll on educational institutions. There is also a general feeling among Zambians that those who access higher education should finance it because of the private benefits that come with it (Mwelwa, 20I4). The neoliberals see taxpayer finance as regressive. They think university students are disproportionately from middle-class backgrounds. If higher education is paid largely or wholly from taxation, the taxes of poorer people pay for the degrees of people whose parents tend to be better off, and who themselves will go on to 
be among the better off (Barr, 2008).

Since tax funding was increasingly becoming inadequate, government introduced cost sharing in university education to make the higher education sector efficient and viable (MOE, I996; Masaiti, 2013a). On I3 June 20I2, the Minister of Education made a policy announcement which indicated that the current student bursary scheme would be phased out and replaced by a loan scheme. He intimated that "the current bursaries system did not meet the expectation of the general public and did not benefit vulnerable students, henceforth; the loan scheme was going to be tabled at the next sitting of Parliament" (Times of Zambia, 20I2, p. 2; Masaiti, 20I3a). The need for such a shift in student financing policy was based on the desire to promote cost recovery, and increased access and participation in higher education for more poor Zambians. For instance, in line with its party manifesto, the Zambian government envisaged the need to reform the student financial aid system in order "to ensure that beneficiaries of bursaries either repay or "work off" the benefit they received, so that the bursary fund is essentially a revolving fund" (PF, 20II, p. 9).

Though the government, through the Ministry of Education, has not clearly indicated whether it will follow traditional or income-contingent loan repayments for students, it appears that Income-Contingent Repayments (ICR) are being advocated for. ICR are repayments calculated as $x$ percent of the borrower's subsequent earnings, collected alongside income tax (Johnstone, 2004; 2009). The loans will cover fees and also living costs. It is not clear how means testing will be done in Zambia because of complexities and technical difficulties in verifying parental ability to contribute and calculating interest. The government will be the main financier of the student loan scheme (MOE, I996).

Against this background, this study investigates the reactions of Zambia's public university students and their perspectives regarding the intended transformation, based on the loan policy as it appears in the current higher education policy. The study helps suggesting appropriate ways of conceiving this transformation. Measuring the level of student support regarding this policy, and identifying what they see as possible impediments to its implementation, is crucial. The aim therefore is also to provoke a debate on the best possible way to implement the student loan scheme system in Zambia. It is a general view that the current system of financing public higher education in Zambia is flawed and lopsided; it has also generated controversies bordering on partisan political debates among different stakeholders (Beyani, 2009). This is because the bursary scheme had not adequately benefited the less privileged in society to equitably access higher education, com- pared to the elite (National Assembly, 20II). This is in some way an African problem. Johnstone (2009) presented evidence on how loan schemes were problematic worldwide, with Africa facing the most challenges regarding management and implementation. This article may therefore help in streamlining the student loan policy. This article has four objectives:

i). To give empirical evidence on the views of students regarding the loan scheme policy;

ii). To deduce underlying factors to the current student loan policy in Zambia;

iii). To highlight lessons for Zambia on loan schemes from international perspectives;

iv). To provide suggestions on how to make the student loan policy sound enough for implementation in Zambia.

\section{Literature Review and Theory on Student Loans in Higher Education Financing}

Literature has been reviewed to show why tax funding is no longer a viable and sustainable way of sponsoring students in higher education (Pillay, 2009). Most countries are now introducing loan schemes as a way of mitigating the issue of access of needy students who cannot afford the cost of higher education (Pillay, 2009). Literature on both developed and developing countries that have had a student loan scheme for a long time is highlighted. Close focus is given to the role of government and management of the loan schemes. Most literature reviewed covers international experience, including government policy resorting to student loan schemes as a way of financing higher education for needy students. Current literature on Zambia is also highlighted.

Barr (2008) makes a case on why tax funding should be discouraged. Other proponents have widely argued that a system of fees and loans harms access, and hence higher education should be financed from taxation (Woodhall, I992; Cortright 200I). For neoliberal economists, the preceding argument is a mistake. Specifically, they contend tax finance does not achieve the objectives of access and quality assurance. Taxpayer finance puts quality at risk. It is further argued that it was possible to rely on taxation to finance a high-quality system when the system was small (Barr, 2008). More clearly, he states that "there are limits to taxation, so that with a mass system, higher education will lose in the political battle to more urgent and politically salient public spending priorities, including nursery and school education, health care, and spending on pensions in the face of population ageing (Barr, 2008 p.6).” 
There is evidence worldwide that real funding per student declined sharply over the years in many countries, as student numbers increased (Slaughter \& Rhoades, 2004; Pillay, 2009). In addition, it is argued that, even if taxpayer finance on a sufficient scale were desirable, it is not feasible (Barr, 2008). Nor does taxpayer finance widen participation. Clearly, some latest studies show otherwise.

Neoliberal education economists are of the view that public funding is supplemented by private funding, but in such a way that higher education is free to the student-it is the graduate who makes repayments, but only in a way that is consistent with his or her future earnings so that it does not become an insurmountable burden for the graduate (Levin, 2006; Kandiko, 20I0). In countries like Zambia where the middle class is difficult to define, and where most students claim to come from vulnerable backgrounds, the preceding argument becomes very difficult to comprehend with. The reality though is that people who access either tertiary or more specifically university education in Zambia come from relatively better-off backgrounds (Carmody, 2004; Masaiti, 2013b).

Good policies, especially in financing higher education, need to be founded on economic theory (Barr, 2008). Barr presents three central propositions that underpin reform in advanced countries and even developing countries: competition is beneficial; graduates should contribute to the cost of their degree; and well-designed student loans have core characteristics (Barr, 2008). Clearly in most countries where higher education is mostly funded through centralized systems as in Zambia, this ideology is though not favoured as they perceive economic theory as harmful to access. Students who are consumers are generally well informed and able to plan and make choices based on the market (Barr, 2009).

Student loan schemes are also complex, widely misunderstood, sometimes misrepresented, and frequently contested (Johnstone, 2009). Certain sections of stakeholders have argued that introducing such a policy would harm access to education and therefore delay further development of the much desired human resource. The forgoing arguments for or against are not easy to comprehensively advance. However, international experience and evidence show that well-designed student loans can especially promote access (Shen, 2007; Barr, 2005).

The objectives of a student loan system are numerous. They include, among others: facilitating the expansion of higher education; cost sharing and cost recovery; easing the financial burden of both country and students; improving quality of access of higher education; and increasing human capital (Ziderman, 2002; Shen, 2003; Barr, 2009). What is clear for public universities in Zambia is that free government support for the majority of their students has strained public resources in a manner no longer sustainable. Given this precarious situation, the government put in place a loan scheme policy (MOE, I996).

\section{But what exactly is a student loan scheme?}

Johnstone (2009, p.I) succinctly defines a student loan system as "any repayment obligation resulting from a scheme designed especially for students-generally with governmental sponsorship and some element of governmental subsidization and/or assumption of risk-to defer higher educational expenses and to incur thereby a repayment obligation, whether this obligation is actually called a loan or by some euphemism, and whether the obligation is to a fixed schedule of payments or is expressed as some percentage of the borrower's future earnings."

Student loans are a means of deferring payment for higher education to a time when students are employed and can afford to pay (Mohadeb, 2006). By implication therefore, student loan schemes allow students, taxpayers, and parents to shoulder part of the costs of higher education, mostly tuition and other fees (Albrecht \& Ziderman, I993). Student loan schemes vary enormously in purpose and cover tuition or part of tuition, living costs, or both. Some argue that they mostly benefit government, since the new revenue from the fees that are covered by new loans simply allows the government to decrease its share of current operating revenues (Johnstone, 2009). Student loans can also accrue to the parent, as when an up-front fee paid mainly by parents is shifted to a deferred fee paid mainly by the student. The loan system also impacts a new flow of revenue that can accrue to the students themselves in greater living expenditures (Ibid, 2009).

Student loans in higher education finance are looked at as one way or some form of cost sharing. Cost sharing in university education refers to a shift in the burden of university education costs from being borne exclusively or predominately by government, or taxpayers, to being shared with parents and students (Johnstone, 2002; 2003). There are many arguments in favor of student loan systems, including views that tax funding cannot sustain the ever-growing industry of higher education, and that higher education has private benefits which transcend social needs (Barr, 2009). Therefore, graduates should contribute to covering the costs of their degrees (Saunders, 2009). In addition, unlike systems based on tax funding which discriminate, and hinder access of those who cannot afford to pay, loan schemes, when properly implemented, are likely to promote access and participation by making higher education free at the point of use (Barr, 2004). 
Many scholars, especially those who advocate market ideology, have argued that higher education creates benefits beyond those to the individual-in terms of growth, the transmission of values, and the development of knowledge for its own sake (Levin, 2006; Barr, 2009). However, what is also clear is that graduates receive significant private benefits in terms of higher earnings, more satisfying jobs, and/or greater enjoyment of leisure, making it inevitable and equitable that they bear some of the costs (Barr, 2009). However, it is important that graduates should bear those costs when they can afford them-as graduates-not while they are students. One clear way students can afford this cost is by looking at the option of designing student loan systems that have core characteristics (Ibid, 2009).

As the goal of cost sharing gains popularity, countries provide public funds not only directly to institutions, but in a growing share, indirectly, to students and their families. These funds are allocated in the form of grants and scholarships, tax benefits and a myriad of student loans (De Villiers \& Nieuwoudt, 20Io). Indeed no cost sharing policy can be implemented equitably without a well-functioning student loan program to make funds available to needy students who would want to borrow for their education (World Bank, I994:46). Student loan schemes have become common and widespread throughout the world, at least in more than 75 countries (Shen and Ziderman, 2007). Their introduction in these countries is premised on the understanding that student loan programs are able to expand real cost recovery from students, in addition to promoting higher education participation and accessibility. (Johnstone, 200I). In the section below we examine and review different cases of student loan schemes from the perspective of five countries: China, the United States, Great Britain, South Africa, and Kenya.

\section{Selected Country Cases on Student Loan Experience China}

In China, there are a number of financial aid measures for students in tertiary education (private and public). These include, among others: grants, scholarships, work study, and student loans (Shen and Li, 2003). The loan system falls under two categories, the old and new system. The new system started operating in 2000 after its introduction in I999 (Ibid, 2003). Since then, the Chinese government has kept on making changes to this policy to improve the loan system. What is clear for China is that a means-tested Government Supported Student Loan (GSSL) is available to cover both tuition and living expenses. Loans are disbursed by state-owned commercial banks, up to a maximum of
CNY 8,000 (US\$1,I72) per year (Shen and Li, 2003). Interest rates are pegged to the rates used in commercial loans within the same repayment period. Interest is charged from the origination of the loan, with almost half paid by the government. By and large, monthly or quarterly repayments begin six months after completion of studies, with a maximum repayment period of four years (Shen, 2003; Johnstone, 2009).

China has several challenges with its current loan scheme. Sun and Barrientos (2009) observe that since there are no comprehensive markets and effective credit systems in China, loans are seldom used, especially among students from low income households. Usually students are deterred by lack of information and high opportunity cost of future debt (students have no collateral which a private lender uses as basis for lending). There have been serious problems of high default rate in implementing the loan scheme. Li and Cui (2004) report that Xian Communication University was the first to be suspended by banks in 2002 from applying for student loans, due to a high default rate of 50 percent. In 2004, Zhengfa University of Trade Centre was also suspended by Industrial and Commercial Bank of China from applying for student loans. Between 2003 and 2004, the average default rate was nearly 20 percent, which was too high for any bank to absorb. In 2004, the government introduced a new system meant to continue the loan scheme with government support through subsidized loans (Sun and Barrientos, 2009). In the new scheme, students were expected to pay back the loans within six years after graduation, but there was no threshold for repaying. As a way of mitigating the risk of default to the bank, the government and university jointly set up what is called a "Risk Compensation Fund for the Bank", approximately 6 percent of the contract value. Government and university pay 50 percent of the compensation fund respectively to the contract bank. Following this arrangement, the government signed an $\mathrm{MoU}$ in 2006 to facilitate the new policy (Ibid, 2009).

\section{United States}

In the United States, there are several types of publicly supported student loan programs whose eligibility criteria and terms differ according to the students' socioeconomic background (Johnstone, 2009). These include: Federal Perkins Loans which are loans that are made available by participating schools using Perkins funds received from the U.S. Department of State to most needy undergraduate and graduate students (Ibid, 2009). Usually, the maximum loan for undergraduates is US\$4,000 per year at an interest rate of 5 percent. Students have to 
honour up within Io years to repay their schools (Ibid, 2009). Other types include Stafford Loans, Federal Family Education Loans, William D. Ford Federal Direct Student Loans. The maximum loans may not exceed a student's unmet financial need and are subject to annual aggregate loan limits of US\$3,500 for the first year, US $\$ 4,500$ for the second, and US $\$ 5,500$ for the third year and beyond. All Stafford loans carry an interest rate of 7.22 percent for loans in repayment (International comparison project ICHEFAP, 2009). This was the practice as of 2007. The repayment period depends on the amount of the loan and the repayment plan that is chosen, and ranges from to to 30 years.

The United States has a long history with loan schemes, which have benefited its citizenry. The loan schemes though have had a fair share of challenges even there, including a rise in default, unemployment and debt, and the relatively high percentage of older borrowers. Briody (20I2) points out that about five million federal loan borrowers are in default and also about 850,000 private loans are in default. In total, this adds up to about US\$67 billion of defaulted student loans. The government through the education department has hired private debtcollection companies to deal with students who have defaulted (Briody, 20I2). The problem is further exacerbated as graduates are not guaranteed a job after graduating. For instance, the Consumer Financial Protection Bureau reports that for private loan borrowers who started school in the 2003-2004 academic year and entered the job market in 2008 (graduating within four years), the unemployment rate was I6 percent in 2009. Another challenge for the United States is that the loan problem does not only concern young people. Barclays reported that 15.5 percent of outstanding student loan balances are held by Americans aged 50 to 59 , and 4.2 percent are held by those 60 and older. The average remaining debt balance for borrowers over 60 is US\$I8,250.

\section{Great Britain}

Zambia has learnt and benefited immensely from Europe, especially Great Britain (its former colonial power), whose models are reflected in most key sectors of the economy. In Europe, by 200I, private costs and benefits of student loans systems were very different from one country to another, and these systems had not reduced the differences in the schooling costs borne by European students or their families (Guille, 2002). On the contrary, in half of the countries in south- or mid-western Europe, student aid was and still is rather low and still comprises no loan scheme, while in the others, the loan component of student support has recently been increased, as in the United Kingdom, or reduced, as in Germany, Sweden, and Norway (Guille, 2002). In other words, in most of Europe, students enjoyed free higher education. England was the first country to break this tradition and introduced more-than-incidental tuition fees (Johnstone, 2009), with students allowed to defer the fee with some kind of a loan and avoid up-front payment. Fulltime students in England are eligible for income-contingent loans to cover their full tuition fees which should not go beyond GBP 3,000 (US\$4,793) and can apply for means tested maintenance loans which differ depending on locality. These student loans carry a zero real rate of interest. Repayment is income contingent (Ibid, 2009). In England, student protests have been common because of the ever increasing costs and future accumulating debt for the beneficiary.

\section{South Africa}

South Africa is a regional power house in economic terms, not only in the southern part of Africa where Zambia is located, but for the entire continent. The National Student Financial Aid Scheme of South Africa (NSFAS) provides a sustainable financial aid system including study loans and bursaries, allowing academically deserving and financially needy students to realize their potential and hopes for the future (www.nsfas.org.za, 20I2). NSFAS in South Africa awards means tested loans between ZAR 2,000 (US\$247) and ZAR 32,500 (US\$4, oI7). The interest rate is relatively high as it includes both inflation and two-percentage-points, with no in-school interest subsidy (Gurgand et al., 2OII). Students who pass all of their courses may qualify for a 40 percent rebate on their loans, and those who pass half of their courses may quality for a 20 percent rebate. Repayment is income-contingent, beginning with 3 percent on the first income, progressively adding an additional I percent for each annual income increment until a maximum of 8 percent of income must be paid for student debt retirement at an annual income of ZAR 59,300 (US\$8, 006) and above (ICHEFAP, 2009). While the national tax and pension contribution systems are not used for collection, special legislation allows NSFAS to require employers to deduct loan repayments from the monthly salaries of graduates. The biggest challenges for the South African student loan scheme are the recoveries and the high interest associated with the scheme.

Kenya

In Kenya, the Higher Education Loan Board (HELB) administers student loans, which are means tested and available only to students who qualify for the government subsidized module (first entrants in university courses), and those who are studying in private universities. The loan covers about three quarters of the yearly higher educa- 
tion costs that must be borne by the student and family (Johnstone, 2009). When the student loan program was introduced in I995, students received a maximum amount of KES 42,000 (US\$II60). This amount was increased in the 2005-2006 financial year to a maximum loan amount for the poorest student of KES 55,000 (US\$760) and a minimum of KES35,000 (US\$484). Once HELB determines that a student should be awarded a loan, the Loans Board pays KES 8,000 (US\$ IO6) directly to the university towards the student's tuition costs (ICHEFAP, 2009). The remaining loan funds are paid to the student through his/her bank account for food and lodging costs and other living expenses. No interest is charged during in-school years and a grace period of one year, and is set at 4 percent during the repayment period. Borrowers are obligated to begin repayment one year after completion of studies. The Board has the right to require employers to deduct repayments from the borrower's wages. In Kenya, government is the source of the funding for the loan but the ultimate risk lies on cosignatories. Giving means tested loans and poor recoveries remain challenging for Kenya.

One of the biggest policy dilemmas Zambia faces is to identify students who are capable of paying competitive fees, as record-keeping and tracking the socioeconomic status of parents is rather fragile and weak. In a study entitled "Means Testing: The Dilemma of Targeting Subsidies in African Higher Education", Tekleselassie and Johnstone (2004) explored among other issues the difficulties inherent in the use of means testing to distribute higher education subsidies based on need or ability to pay in Africa. They discovered that since income in Africa is often hidden due to the nature of the economy, the use of categorical indicators such as race/tribe/ethnicity, parents' education, and assets, among others, is often used to determine a student's ability to pay for higher education. The article argues that while these measures are not perfect, they do provide some rough justice that is preferable to equal subsidies to all regardless of their ability to pay.

\section{Studies on Zambia and Existing Gaps}

In Zambia, a few studies have been conducted on student and higher education financing policies (Mwemba, 2003; Masaiti \& Shen, 2013; Masaiti, 20I3; and Mwelwa, 20I4). For instance a study by Mwemba (2003), entitled "The Coping Strategies of the University of Zambia Students with Cost Sharing in Financing Higher Education", sought to establish the actual ways in which students, especially those who were not on, or fully supported through, the bursary scheme by the government, coped with cost sharing in financing their education. The study further sought to establish the students' ability to meet the requirements of cost sharing. It was established that students engaged in different coping strategies such as saving part of their meal and project allowances, doing part-time jobs, getting conventional loans, and pushing for Ioo percent government support, while others withdrew from their studies to raise the needed money. This study recommended, among other things, to consider implementing the student loans scheme for vulnerable students to continue with their university education.

In addition, a study by Masaiti and Shen (2013) explored students' perspectives over the cost sharing policy. The study sought to identify the underlying factors that could improve the viability and effectiveness of the cost sharing policy in the financing of public universities. The study revealed that the cost sharing policy was appropriate, though it lacked government support to ensure its effective implementation. It also revealed that effective implementation of the cost sharing policy was the only way through which public universities were going to be more efficient, cost effective and sustainable in the provision of higher education. The study discussed different actors involved in cost sharing including the government, students, the universities, and other stakeholders. It can be said that the student loan scheme has not been given much attention and has not been much discussed, especially by the government.

In 20I3, in a study entitled "Re-engineering Public University Financing Policy in Zambia”, Masaiti used Johnstone's (I986) "Diversified Funding Model" (DFM) in the conceptual framework to appraise the policy for financing public universities that had been in existence for almost two decades in terms of cost sharing, revenue diversification, and student loans. The study theoretically and empirically used the "parallel convergent mixed design", in which quantitative and qualitative approaches are juxtaposed. In light of the aggregate actors' perceptions concerning the policy of financing public universities, findings of the Masaiti study suggested that the current policy was perceived to have had a modest achievement and therefore needed to be reengineered to become viable, effective and sustainable. The study did not get into the intricate detail of the student loan schemes. The model used generally tested the overall financial arrangements to public university finance in Zambia.

Lastly a study by Mwelwa (20I4) sought to investigate the possibility of designing and implementing a loan scheme as a viable cost sharing measure to promote equitable access to higher education in Zambia. One of the major findings of this study was that, though Zambia had the potential to implement the scheme, a number of necessary conditions 
to ensure its success as a revolving fund were missing. Though this study focuses on the shift from the bursary scheme to a loans scheme, it is at variance with the previous studies in a number of ways. The study by Mwelwa (20I4) focused on a small sample (I45 students from two public universities), while this study is based on a larger representative sample (729 students from three public universities). In addition, the study by Mwelwa was more qualitative and less quantitative, while this one is purely quantitative and thus more scientifically rigorous. Lastly, this study solely focuses on the reactions of students regarding the implementation of the loan scheme, while the previous included different stakeholders in education as key informants, such as education administrators, economists, parents, and students, on the best way to implement the loan scheme in Zambia. This study, therefore, is meant to strengthen some methodological weaknesses in Mwelwa's study, regarding the sample size and data analysis. Unlike others in the past, this study focuses on student reactions to the introduction of the student loan scheme and cost sharing.

\section{Methodological Considerations}

While this article reviews student loan scheme approaches from an international perspective and gives empirical evidence on Zambian student perceptions regarding the loan and bursary schemes, literature on this subject is vast. The authors have deliberately selected papers, articles, and publications especially based on current experience. The study, which employed descriptive statistics and advanced multivariate analysis, takes into account views of students from the three largest public universities in Zambia: the University of Zambia (UNZA), Mulungushi University (MU), and Copperbelt University (CBU). Though Mulungushi University is classified as a public university, its operational model, which is private, presents a different perspective.

We thought views from well-established universities with a clear track record were more credible, hence the selection of these institutions for this study. The number of private universities in Zambia has grown considerably in the last ro years and future studies should also consider such institutions.

A sample of 729 students was employed for this study (See table I). The convenient proximity and accessibility to a large number of students, who readily volunteered to participate in the study, necessitated the use of a convenient sampling approach. Quantitative data was collected through a structured questionnaire in order to collect accurate and complete responses. Excel data was loaded into Statistical Package for Social Sciences (SPSS) in which descriptive statistics were used to examine specific variables from a structured survey questionnaire with I2 items. The I2 items were further reduced to four key items related to: cost effectiveness and sustainability; loan aid condition appropriateness; satisfactory transformation; and giving hope and confidence to vulnerable students. One might argue that $\mathrm{I} 2$ items cannot be subjected to factor analysis, but the only accurate way of loading and scrutinizing how underlying constructs manipulate the responses on a number of calculated variables was through factor analysis. Henceforth, factor analysis was performed to determine the underlying factors to the current student loan policy.

Table 1. Respondents: Distribution by Selected Demographics for Students

\begin{tabular}{|l|c|c|}
\hline Demographic & Variable & Valid Percent (\%) \\
\hline \multirow{3}{*}{ Gender } & Male & 55.3 \\
\hline \multirow{4}{*}{ Age } & Female & 44.7 \\
\cline { 2 - 3 } & up to 30 & 63.2 \\
\cline { 2 - 3 } & $31-40$ & 23.4 \\
\cline { 2 - 3 } & $41-50$ & 11.7 \\
\cline { 2 - 3 } Institution & 50 and older & 1.7 \\
\hline \multirow{3}{*}{ Sponsor } & UNZA & 61.9 \\
\cline { 2 - 3 } & CBU & 11.4 \\
\cline { 2 - 3 } & MU & 26.7 \\
\hline & Self & 65.6 \\
\cline { 2 - 3 } & Government & 31.4 \\
\cline { 2 - 3 } & Other & 2.6 \\
\hline
\end{tabular}

\section{Results}

\section{What are the Perspectives (Reactions) of Zambian Students?}

Perspectives on student's views (reactions) about the announcement to introduce loan systems were collected using a structured, closed-ended questionnaire. A five-point scale was used to determine and describe the extent of support; I= Do not support; $2=$ Low support; $3=$ Moderate support; $4=$ Support; $5=$ Strongly support

Figure I shows that students strongly support the introduction of the student loan scheme as a cost effective and sustainable way of stabilizing public universities. 328 (45 percent) strongly agree, I88 (25.8 percent) agree, I05 (I4.4 percent) are moderate, 34 (4.7 percent) disagree and 73 (Io percent) strongly disagree. Clearly, as shown in Figure I, over 70 percent of the students support the introduction of the policy, unlike previous assumptions that the student population is opposed to the introduction of a student loan scheme. 
Figure 1. The Loan Aid Scheme is a Cost Effective and Sustainable Way in University Finance

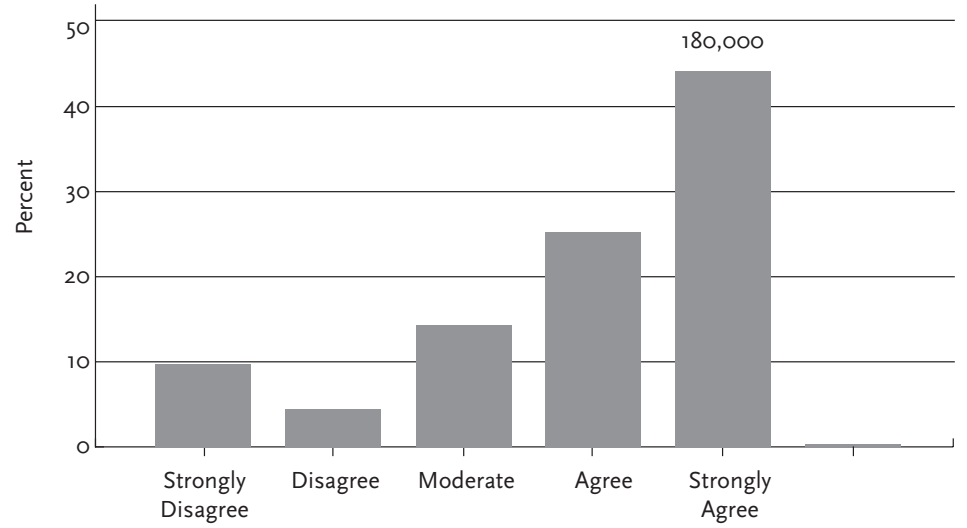

Figure 2. The Current Loan Conditions are Appropriate

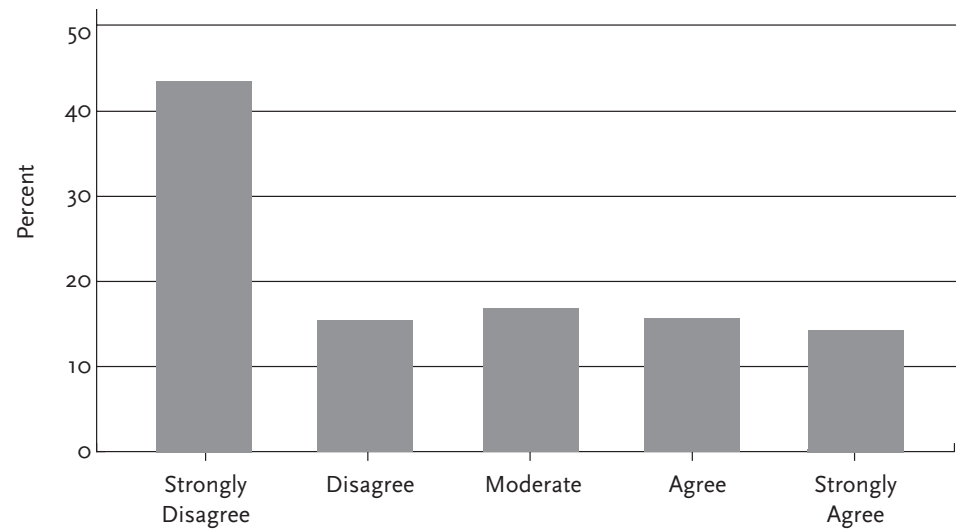

Figure 2 shows the students' reaction to the conditions associated with the loans. Though the government has not clearly defined and stated the terms of borrowing, what is clear is that the scheme will not be premised on a merit system, but on means testing. Only students who cannot afford the cost of university education will be supported, representing a clear shift from the current trend. Students also know that all those who will enjoy the facility have to pay back in some way in future. Based on this score, few students, under 30 percent, support conditions surrounding the loan scheme. About 300 (4I.2 percent)
Figure 3. The Whole Transformation From Bursaries to Student Loan Aid is Satisfactory

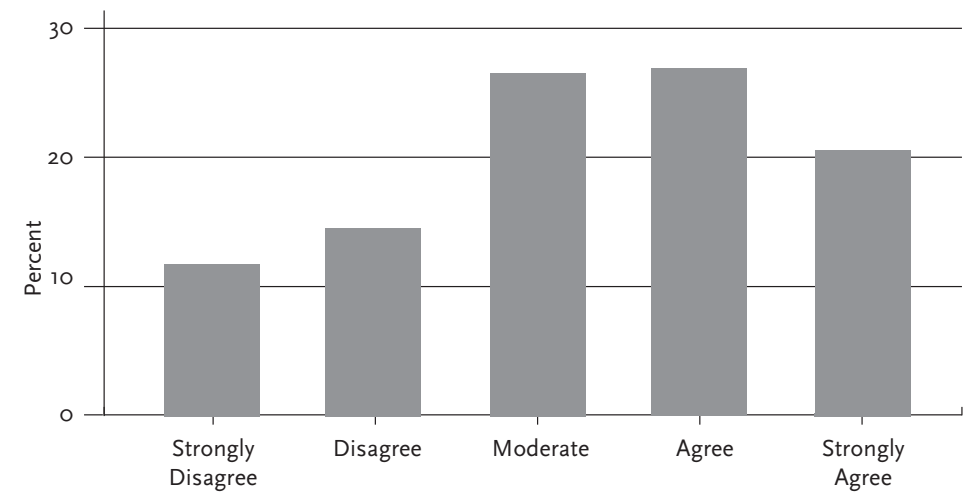

strongly disagree, Io6 (I4.5 percent) disagree, II6 (I5.9 percent) are moderate, Io8 (I4.8 percent) agree and 99 (I3.6 percent) strongly agree as shown in Figure 2.

Getting student reactions and perceptions on how they conceive the whole process of transforming the bursary scheme into the student loan scheme was crucial, because this affects them either directly or indirectly. The responses on this score are mixed, though a majority support this transformation. Out of the 729 students, I49 (20.4 percent) strongly support, I96 (26.9 percent) support, I93 (26.5 percent) are moderate, I05 (I4.4 percent) show low support and 86 (II. 8 percent) do not support, as shown in Figure 3.

Most students are very concerned about the issue of access once the loan scheme is introduced. They want a loan scheme which should be inclusive and shield especially the poor and vulnerable students. They show a positive perception, in that they have hope and confidence that the anticipated loan scheme will provide a cushion to needy students. All items related to the benefit of student loans to poor students are overwhelmingly supported. Of the 729 respondents, 500 (68.6 percent) strongly agree, I22 (I6.7 percent) agree, 52 (7.I percent) are moderate, only 25 (3.4 percent) disagree and 30 (4.I percent) strongly disagree as shown in Figure 4. Overall, more than 85 percent of the respondents agree on this issue.

We further performed a factor analysis to identify the underlying factors to the current student loan policy, based on I2 student loan policy items. 
Figure 4. The New System Gives Hope and Confidence to Poor and Vunerable Students

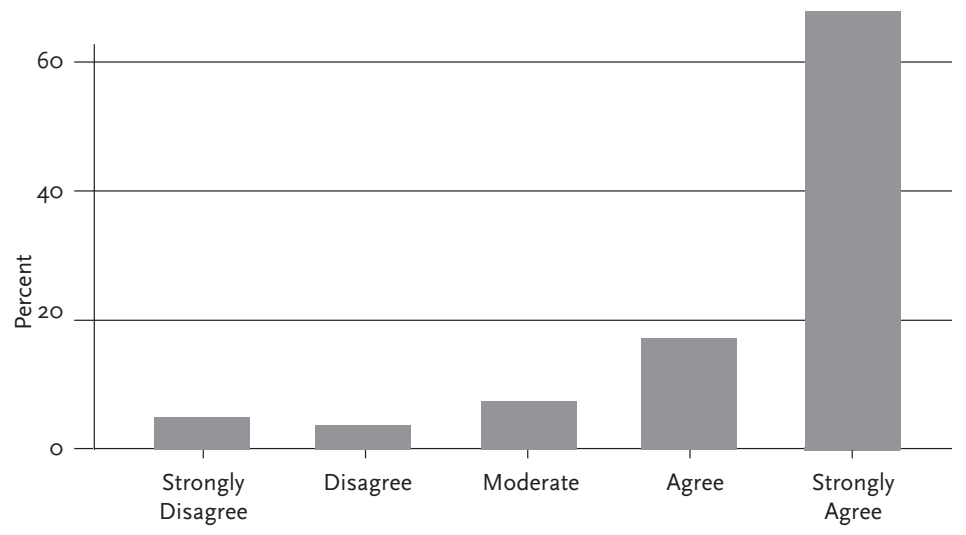

\section{Factor Analysis}

Initially, the factorability of the I2 student loan policy items was examined. Several well-recognized criteria for the factorability of a correlation were used. Student loan policy items correlated at least 0.3 with at least one other item, suggesting reasonable factorability. Secondly, the Kaiser-Meyer-Olkin measure of sampling adequacy was 0.63 , above the recommended value of 0.5 , and Bartlett's Test of Sphericity was significant $\left(\chi^{2}=\right.$ II4I. $844, p<.05$ in fact, $p$ was significant at $\left.<0.00 \mathrm{I}\right)$. The diagonals of the anti-image correlation matrix were all over 0.5 , supporting the inclusion of each item in the factor analysis. Finally, the communalities were all above 0.3 , further confirming that each item shared some common variance with other items. Given all these overall indicators, factor analysis was conducted with all I2 items.

Principle components analysis was used because the primary purpose was to identify and compute composite coping scores for the factors underlying the student loan policy as it appears in the current Zambia policy documents. The initial eigenvalues showed that the first factor explained I9.2 percent of the variance, the second factor I5.3 percent of the variance, and a third factor I2.2 percent of the variance respectively. Then the fourth was 8.4 percent. From the table of "initial solution", the "eigenvalue" is the variance explained by each factor. Any factor that has an eigenvalue of less than I does not have enough variance explained to represent a unique factor, and therefore disregarded. In this analysis, we have to note that component 5 going down have eigenvalues less than I.O, so they have been eliminated from the analysis (5 to I2 eliminated) though together they represent a variance of about 43 percent.
Varimax (orthogonal) rotation of 12 of the Likert scale questions from this student loan attitude survey questionnaire was conducted. The pattern matrix for varimax rotation reports the factor loadings for each variable on the components of factors after rotation. The path analysis, showed 4 topic factors as shown in Table 2.

Table 2: Factor loadings and communalities based on a principle components analysis with Varimax rotation for 12 items from the student loan policy

\begin{tabular}{|c|c|c|c|c|}
\hline \multicolumn{5}{|c|}{ Rotated Component Matrix } \\
\hline & \multicolumn{4}{|c|}{ Component } \\
\hline & 1 & 2 & 3 & 4 \\
\hline $\begin{array}{l}\text { Q50. There are no guidelines to the universities to effect } \\
\text { the student loan policy }\end{array}$ & .760 & & & .157 \\
\hline $\begin{array}{l}\text { Q49. The policy was hurriedly done without examining } \\
\text { the pros and cons of student loan policy }\end{array}$ & .678 & .209 & -.114 & .100 \\
\hline $\begin{array}{l}\text { Q53. Government and public universities are slow to } \\
\text { respond/adjust to student loan system }\end{array}$ & .642 & & .229 & \\
\hline Q48. Zambian public are opposed to student loan policy & & .794 & & \\
\hline $\begin{array}{l}\text { Q47. Student loan system is always opposed by Student } \\
\text { populous }\end{array}$ & & .778 & -.254 & \\
\hline $\begin{array}{l}\text { Q51. It was difficult to find guarantors for the loan policy } \\
\text { (Relatives/guardians to secure the loan) }\end{array}$ & .308 & .453 & .279 & -.216 \\
\hline $\begin{array}{l}\text { Q54. There is need for creation of a special Bank to } \\
\text { manage the Student loan policy }\end{array}$ & & & .674 & .223 \\
\hline $\begin{array}{l}\text { Q55. Student Loan policy is a cost effective way of } \\
\text { assisting students from vulnerable background }\end{array}$ & & -.185 & .655 & \\
\hline $\begin{array}{l}\text { Q52. The criteria for deserving students should have } \\
\text { been complicated (Means testing is very difficult in } \\
\text { Zambia—who qualifies for the loan?) }\end{array}$ & .303 & .347 & .541 & -.124 \\
\hline $\begin{array}{l}\text { Q44. Student loan policy is a good way of financing and } \\
\text { sustaining public universities }\end{array}$ & & -.167 & .510 & -.164 \\
\hline $\begin{array}{l}\text { Q46. Student loan system has never been implemented } \\
\text { because of public university Inertia }\end{array}$ & & & & .838 \\
\hline $\begin{array}{l}\text { Q45. Student loan policy has never been implemented } \\
\text { because of government Inertia }\end{array}$ & .230 & & & .803 \\
\hline $\begin{array}{l}\text { Extraction Method: Principal Component Analysis. } \\
\text { Rotation Method: Varimax with Kaiser Normalization. }\end{array}$ & & & & \\
\hline
\end{tabular}


After running factor analysis on the I2 items related to the current loan policy, four factors were identified as crucial, namely:

Three items loaded onto Factor I and these were related to respondents' perceptions regarding the clarity of the current cost sharing policy. The factor was labelled as "No clear guidelines for the current student loan policy". Factor 2 explored items related to different segmentations for the support of the current loan policy by Zambia. All three items related to whether students and Zambians are opposed to the current policy were loaded. The factor was labelled as "Zambians not opposed to student loan policy". Three items were loaded onto Factor 3 related to the major beneficiary of the student loan policy. The factors were labelled as "Student loan policy are crucial for vulnerable students" and Factor 4 loaded items related to why the loan policy has never been implemented. The items explored whether universities or students were a hindrance in implementing this policy. The factor was labelled "Government inertia is the cause of lack of implementation of the loan policy".

\section{Discussion}

Earlier studies (Mwelwa, 20I4; Masaiti 2013a) conducted at only one university (University of Zambia) and showing student support to the loan scheme, had generally smaller samples and were mostly qualitative. This study sampled three universities in different regions with relatively different dynamics and models of operation as explained earlier. This study goes further and gives reasons why students support this policy, in particular because they perceive the loan system as a better and more cost-effective way of assisting students from vulnerable backgrounds, and they feel that the student loan scheme is a good way of financing and sustaining public universities. It is also important to mention that the current study solely focuses on the reactions of students regarding the implementation of the student loan scheme, while previous studies included different stakeholders in education as key informants, such as education administrators, economists, parents, and students. The limitations of previous studies on Zambia have been captured under "Literature on Zambia".

It is clear from the presentation of the findings above that students strongly support the shift from the bursary system to a loan scheme. In fact, even students that were currently enjoying the government bursaries overwhelmingly supported this shift. Many politicians and political commentators today continue to argue that tax-funded education enjoys student support. It has always been envisaged that the student population is opposed to the loan scheme, but the results from the largest public universities show the contrary. Students, both men and women, from three institutions, have shown overwhelming support for the student loan scheme. As evidenced in Figures I, 2, 3, and 4 and Table 2 , students perceive the loan system as a better and cost effective way of assisting students with a vulnerable background. Their negative perception on the loan scheme is based on the fact that it will be selective and that students will accrue future debt. On the other hand, they also feel that the student loan scheme is a good way of financing and sustaining public universities. Such a student financing policy is essential in a country where the state does not adequately finance the recurrent expenditures of public universities (UNZA, 20I2). Factor analysis deduced four crucial underlying factors behind the current student loan policy in Zambia. Namely, that there are no clear guidelines for the current student loan policy; that Zambians do not oppose the student loan policy; that a student loan policy is crucial for vulnerable students; and that government inertia is the cause of the lack of implementation of the loan policy. On a whole, there is relatively moderate support for the shift from bursaries to a student loan scheme.

One of the biggest financial drains affecting public universities has been government grants to students for tuition, fees, and living allowances. The student loan policy came into being more than a decade ago but has never been implemented, mainly because of political debates and government inertia. This has been established in the earlier study by Masaiti (2013a) conducted in only one university with a sample of 350 students. That could explain why in most African countries, agencies administering such loans as well as top agency personnel seem constrained from effectively carrying out their duties by politicians who have no understanding of the economics of loans and repayments or are afraid of alienating voters (especially student bodies) by supporting interest rates, rationing and collection methods, which are essential to real cost sharing (Ziderman, 2005).

When asked about the best way to allocate public resources in an environment where government taxes can no longer cover the operations of public universities and, worse still, the cost of sponsoring poor students in public universities, most students felt the introduction of the loan system could be the ideal way of helping students from poor backgrounds, while others should pay economic and competitive fees. Over 70 percent at least agreed on the introduction of the loan system as a way of supporting public universities while assisting needy students (Masaiti, 20I3b), with the justification that any effective policy in higher education financing must embrace and promote access, equality and sustainability (IDPM, 20I2). 
Figure 5. Summary of perceptions on student loan policy

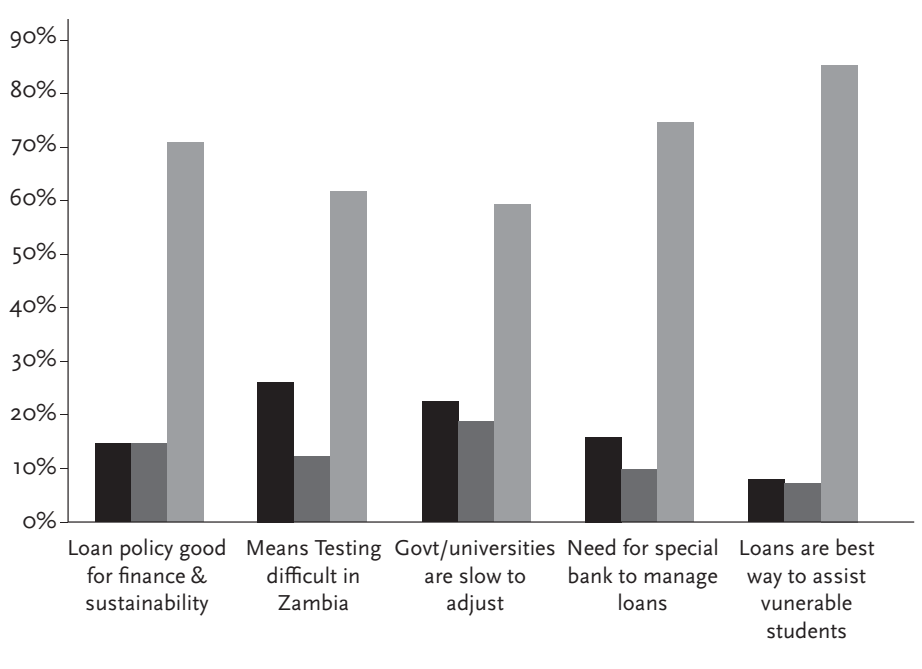

Disagree (\%) —Moderate (\%) Bachelors

In summary, both descriptive statistics and factor analysis show five items, which were perceived to have the greatest impact on the respondents: "The loan policy is a cost effective way of assisting students from vulnerable background" with the support of 85.3 percent (7.I percent moderate, 7.5 percent low support); followed by "need for creation of special bank to manage the student loan scheme" with 74.7 percent support ( 9.6 percent moderate, I5.8 percent low support); loan policy is a "good way of financing and sustaining public universities" with support of 70.8 percent (I4.4 percent moderate, I4.7 percent low support); "giving means tested loans could be a challenge for Zambia" with 6I.7 percent of support (I2.2 percent moderate, 26.I percent low support); and "government/universities are slow to respond and adjust to change" with support of 59.3 percent (I8.4 percent moderate, 22.4 percent low support).

\section{Lessons from International Experience for Zambia Regarding Student}

\section{Loan Schemes}

Woodhall (I992, p.352) highlights key characteristics needed for a successful student loan program, including (i) sound administrative and financial management; (ii) a legal framework that ensures loan recovery is legally enforceable; (iii) effective mechanisms for targeting on the basis of financial need; and (iv) publicity to ensure understanding and acceptance of the terms for borrowing and repayment of loans. Ziderman \& Albrecht (I995, p. 88) further state: (v) a credible collection institution, with incentives to collect; and (vi) a willingness to charge interest rates on loans equal to or above inflation. Since Zambia is at the crossroads of introducing this scheme, all these factors need to be taken in consideration.

Loan schemes are complex and therefore require considerable political will. Any scheme that is generally available requires considerable governmental involvement in setting rates and terms, the provision of subsidies, the provision of capital, the assumption of risk, and/or the actual origination and servicing of the loans (Johnstone, 2009). There are considerable challenges, especially when it comes to repayment. Still, the Zambian government, through the Ministry of Education, does acknowledge that while there are difficulties associated with the effective implementation of the student loan scheme policy, its benefits outweigh them by far (MOE, I996). Leading scholars are working in a collaborative way to propose a new model to ease repayment burden (Shen and Ziderman, 2009).

Specifically for Zambia, the following questions are crucial for policymakers to reflect on, before the loan scheme is fully implemented:

I. Who will be eligible for these loans? Zambia might have a challenge when implementing a fair system of "means-tested loans" (given to deserving students), which is no easy task in countries where transparent financial records and reliable tax collection systems are missing. In Zambia, even asset-rich individuals can be cash poor, and there is typically no objective and easy system to assess the ability to pay.

2. What will the terms of borrowing be? (income contingent, or market interest or others?)

3. What will be the percentage or number of students eligible for loans?

4. In what range will students borrow, meaning the maximum and minimum amount they can borrow?

5. In a country where employment for graduates is not guaranteed, who is going to guarantee the loan or who is going to be the guarantor? In other words, who will bear the ultimate risk?

6 . Will the loan system cater for both public and private higher education institutions, and does the government have enough capital to realize this undertaking?

7. Who will administer the loan scheme? The government, a bank or some other independent agency?

8. What monitoring mechanisms will be put in place? 


\section{Conclusion}

While Zambia has yet to fully exploit the benefits of a student loan scheme, this article argues that student loan schemes have several aims and benefits. They put money into the hands of students to access higher education. They increase the funding of higher education, by moving some expenses from the government to the students. This article produces stronger evidence than earlier studies that students are in support of the shift from the current bursary scheme to a loan scheme.

Unlike views held by some politicians and stakeholders that students are against the loan scheme, the article argues that the opposite is in fact the case, as students consider loans as a more viable way of systematically assisting needy students and making higher education sustainable, provided means testing is strengthened and the right beneficiaries are identified. The article hopes to trigger deep reflection on the pros and cons of student loan schemes in Zambia, taking into account similar international experience.

\section{Recommendations}

i) Since the study has strongly recommended the implementation of the loan scheme, identifying needy students (means testing) is central. It is very difficult for a loan scheme management body to determine who is needy in the Zambian context. The loan scheme commission and the government should develop a strategy to perform an effective and efficient needs assessment, based on reliable national data.

ii) This article recommends a comprehensive review of the loan scheme policy which appears in the current education document, followed by identification of country(ies) with a relatively successful loan scheme program, that Zambia can learn from.

iii) Government involvement and political will are paramount for a successful loan scheme primarily, among others, to inject a massive initial infusion of funds.

iv) Government, through Parliament, should repeal and amend the Statutory Instrument No. 182 of 1973 . Strengthening this legal framework will not only empower the Bursaries Committee with authority to administer the student loans, but also make loan recovery from past beneficiaries legally enforceable.

v) Now that the student loan scheme might be implemented in Zambia, one of the major problems is repayment and loan recovery. Zambia should develop an effective tracking system with a wellmanaged database that will help the loan scheme commission to identify past beneficiaries for possible repayment, with support from government. Government should consider issuing permanent identification numbers to all students to ensure its successful implementation.

vi) This article further recommends that a statutory body should be legally established to administer the publicly-financed student loan scheme to help needy students meet the cost of tuition and access public university education. Such a body should engage commercial banks and tax administration institutions such as the Zambia Revenue Authority (ZRA) and National Pensions Scheme Authority (NAPSA) to collect loan repayments through income tax from beneficiaries in remunerative employment, in both the public and private sectors.

\section{References}

Albrecht, D and Ziderman, A. (I993). "Student Loans : An Effective Instrument for Cost Recovery in Higher Education?". The World Bank Research Observer. - Vol. 8,(1),pp. 71-90.

Barr, N. (2009). Financing higher education: lessons from economic theory and reform in England. Higher education in Europe, 34 (2). p. 201.

Barr, N. (2008). "Financing Higher Education: Lessons from Developed Economies, Options for Developing Economies." In J. linn and P. Pleskovic (eds), Annual World bank Conference on Development economics 2008, Regional: Higher Education and Development. Washington D.C: The World Bank.

Barr, N. (2005). Financing Higher Education: Answers from the UK. London: Routledge Studies in Education.

Barr, N. (2004). Higher Education Funding. Oxford Review of Economic Policy, 20(2): 264-283.

Beele, M. E. (2OI2) " Financing of Public Universities: A Case of Mulungushi”. Kabwe: Mulungushi University.

Brody, B. (20I2). "Shocking Truths about Student Loans in the US": Fiscal Times: Accessed on OI.09.20I2 from: http://thefiscaltimes. com.

Carmody, B. (2004). The Evolution of Education in Zambia. Lusaka: Bookworld Publishers.

Beyani, C. (2009, September). "Re-Engineering Education Towards Vision 2030" Paper Presented at the National Review Consultation Conference: Lusaka.

Coburn, J. (I993, March). "Out of Africa in low-pay. Conference on improving tertiary education in Sub-Saharan Africa: Things that work.".The Glasgow Herald, p.20. 
Cortright, J. (200I). New Growth Theory, Technology and Learning: A practitioners' Guide. Portland, Oregon: Impressa Inc.

De Villier, P and Nieuwouldt, L. (20I0). "Shifting Trends in Higher Education Funding". A working paper for Bureau of Economic Research of South Africa: I2 (iо).

Government of the Republic of Zambia (20II). Sixth National Development Plan 2011-2016. Lusaka: MoFNP.

Government of the Republic of Zambia (2013). Revised Sixth National Development Plan 2013-2016. Lusaka: MOFNP.

Guille, M. (2002). "Student Loans : A Solution for Europe.", European Journal of Education, 35(2), 4I7-433, 2002

Gurgand, M; Lorenceau, J.S.A and Melonio, T. (20II). Student Loans: Liquidity Constraints and Higher Education in South Africa. Agence Française de Dévelopement Working Paper No. II7. Retrieved on I3/08/13 from SSRN: http://ssrn.com/abstract=I969424 or http://dx.doi.org/I0.2139/ssrn.1969424

ICHEFAP. 2009. Higher Education Finance and Cost Sharing Profiles by Country. Available [online] at http://www.gse.buffalo.edu/org/ IntHigherEdFinance/. Accessed Io August, 20I2.

Institute for Development Policy and Management (IPDM). (20I2). How Should Developing Countries Finance Higher Education? University of Manchester, Manchester, UK.

Johnstone D .B. (2009). Worldwide Trends in Financing Higher Education: A Conceptual Framework. Jane Knight: Sense Publishers.

Johnstone D. B. (2009). Conventional Fixed-Schedule Versus Income Contingent Repayment Obligations: Is there a Best Loan Scheme? Financial Support to Students through Student Loans, edited by Adrian Ziderman in Higher Education in Europe. 34 (2).

Johnstone D. B. (2009). Financing Higher Education: Who Pays and Other Issues: Baltimore: The Johns Hopkins University Press.

Johnstone, D.B. (2004). "The Applicability of Income Contingent Loans in Developing and Transitional Countries." Journal of Educational Planning and Administration, I8 (2), I59-I74.

Johnstone DB. (2004). The Economics and Politics of Cost Sharing in Higher Education: comparative perspectives. Economics of Education Review. 23 (4), 403-4IO.

Johnstone, D. B. (2003). Income contingent loans and graduate taxes: Can they work in developing and transitional countries? Prepared for the International Forum of the Association for the Study of Higher Education (ASHE).

Johnstone, D. B. (200I). Cost-Sharing in Higher Education: Tuition, Financial Assistance, and Accessibility. Czech Sociological Review,
39(3), 35I-374.

Johnstone, D. B. (200I). Student Loans in International Perspective: Promises and Failures, Myths and Partial Truths. Buffalo: University of Buffalo. Journal of Higher Education, 77(I), 62-88.

Johnstone, D. B. (2000). Response to Austerity: The Imperatives and Limitations of Revenue Diversification in Higher Education. The International Comparative Higher Education Finance and Accessibility Project, Center for Comparative and Global Studies in Education, . Buffalo, NY: State University of New York at Buffalo.

Johnstone, D. B. (200I). Cost-Sharing in Higher Education: Tuition, Financial Assistance, and Accessibility. Czech Sociological Review, 39(3),35I-374.

Johnstone, D. B. (2003). Income contingent loans and graduate taxes: Can they work in developing and transitional countries? Prepared for the International Forum of the Association for the Study of Higher Education (ASHE).

Johnstone, D.B. (200I). Student Loans in International Perspective: Promises and Failures, Myths and Partial Truths. Buffalo: University of Buffalo. Journal of Higher Education, 77(I), 62-88.

Kandiko, C.B. (20I0). "Neoliberalism in Higher Education: A Comparative Approach." International Journal of Arts and Science, 3 (I4), I53-I75.

Kelly, M. J. (I99I). Education in a Declining Economy. Washington D.C: World Bank.

Kelly, M. J. (1999). The Origins and Development of Education in Zambia: From pre-colonial times to 1996. Lusaka: Image Publishers.

Kelly, M.J. (I99I). The Financing of Education in Zambia. IIEP, UNESCO, Research Report No. 9I.

Levin, J. S. (2006). Faculty work: Tensions between educational and economic values. The

London and Washington D.C.: Falmer Press.

Masaiti, G \& Chita, J. (20I4). Zambia: An Overview of Formal Education. In C.C, Wolhuter and C, Brock (Eds), Handbook on Education in Central and East Africa. Continuum Books: London.

Masaiti, G. \& Shen, H. (2013). Cost Sharing in Zambia's Public Universities: Prospects and Challenges. European Journal of Educational Research. Vol. 2(I), pp. I-I5.

Masaiti, G. (20I3a). "Students' Perceptions of Financing Public Universities in Zambia: Towards a More Sustainable and Inclusive Policy Strategy". In D. Teffera Funding Higher Education in Eastern and Southern Africa: Modalities, Challenges, Opportunities and Prospects. Palgrave Macmillan: New York 
Masaiti, G. (20I3b). "Re-engineering Public University Financing Policy in Zambia: An Empirical Study with a Mixed Method” PhD Dissertation Submitted to HUST, Wuhan.

Ministry of Education (MOE). (I996). Educating our Future: Nationa Policy on Education. Lusaka: Zambia Education publishing house.

Ministry of Education (MOE). (20IO). Ministry of Education Strategic Plan. Lusaka: Headquarters.

Ministry of Education (MOE). (2012). "Minutes for the Commission to Review the 1996 Policy document." Lusaka: Education Headquarters.

Ministry of Education (MOE).(2009). Annual Progressive Report. Lusaka: Pureline Publishers.

Ministry of Education (MOE).(2009). Strategic Plan. Lusaka: Headquarters.

Mohadeb, P. (2006). Student Loans Schemes in Mauritius: Experiences, Analysis and Scenarios. Paris: International Institute for Educational Planning, (IIEP).

Mwelwa, K. (20I4). "Implementation of the Student Loans Scheme policy as a Viable Cost-Sharing measure in Promoting Equitable Access to Higher Education in Zambia." Perspectives of Selected Stakeholders in Education. Unpublished Masters Dissertation, University of Zambia, Lusaka.

Mweemba, D. (2003) “The Coping Strategies of the University of Zambia Students with Cost-Sharing in Financing Higher Education." Unpublished Masters Dissertation, University of Zambia, Lusaka.

Parliamentary Assurances Committee (20II). "Bursaries Committee on Vis-à-vis Student Loans." Report of the Committee on Government Assurances for the Fifth Session of the Tenth National Assembly appointed on 22nd September, 2011.

Patriotic Front (20II). Patriotic Front 2011-2016 Manifesto. Lusaka: Government Printers

Pillay, P. (2009). Challenges and lessons from East and Southern Africa, In J. knight (ed.) Financing Access and Equity in Higher Education. Tapei: Sense Publishers, I9-39.

Saunders. B. (2009). Neoliberal Ideology and Public Higher Education. Journal of Critical Education \& Policy Study, 8(I), 42-76.

Serpell, R. (20I2, December). "Financing and Infrastructure Development at Zambia's Established, New and Future Universities." A response to the Parliamentary Committee on Education, Science and Technology, Lusaka.

Shen, $\mathrm{H}$ and $\mathrm{Li}, \mathrm{W}$ (2003). A review of the student loans scheme in China. UNESCO-Bangkok/IEEP, Asia and Pacific Regional Bureau for
Education.

Shen, H. and Ziderman. A. (2007). Student Loans Repayment and Recovery: International Comparisons._IZA Discussion Paper No. 3588. Bonn Germany: Institute for the Study of Labor (IZA).

Slaughter, S., \& Rhoades, G. (2004). Academic Capitalism and the New economy: Markets, State and Higher Education. Baltimore, MD: John Hopkins university press.

Southern African Region University Association (SARUA). (20I2). "Financing Higher Education in Southern Africa: A guide to public universities in Southern Africa-Zambia" Retrieved on 20.12.2012from http://www.sarua.org/files/Handbook/SARUA\%2oHandbook_ Zambia.pdf

Sun, F. and Barrientos, A. (2009). The Equity Challenge in China's Higher Education Finance Policy. Higher Education Policy,22, I9I-207.

Tekleselassie, A \& Johnstone, D. B. (2004). "Means Testing: The Dilemma of Targeting Subsidies in African Higher Education." Journal of Higher Education in Africa, Vol. 2 (2), pp. I35-I58.

University of Zambia (2012). The University of Zambia Strategic Plan 2013-2017. Lusaka: UNZA Press.

Woodhall, M. (I992). Student Loans in developing Countries: Feasibility, Experience and Prospects for Reform. Higher Education, Vol.23, 347-358.

World Bank (I994). Higher Education: Lessons of Experience. Washington, DC: The World Bank.

Ziderman, A. (2005). Increasing Accessibility to Higher Education: A Role of Student Loans. Moscow: Independent Institute for Social Policy

Ziderman, A. (2002) "Alternative Objectives of National Student Loan Schemes in Maureen Woodhall, ed. Paying for Learning: The Debate on Student Fees, Grants and Loans in International Perspective. Special International Issue of The Welsh Journal of Education, Vol.II, No. I, pp. 37-47.

Ziderman, A and Albrecht, D. (I995). Financing Universities in Developing Countries. London: Falter Press. 